\title{
Oral supplementation of ethanolic extract of Bauhinia variegata leaves did not disturbed the hematological and serum biochemical profile of adult albino mice
}

\author{
Asmat Ullah ${ }^{1,2}$, Shahid Iqbal ${ }^{1,2}$, Muhammad Qasim ${ }^{3}$ and Furhan Iqbal ${ }^{2 *}$ \\ 1. Government Emerson College, Multan-Pakistan \\ 2. Institute of Pure and Applied Biology, Zoology Division. Bahauddin Zakariya University, Multan-Pakistan \\ 3. Department of Bioinformatics and Biotechnology GC University Faisalabad-Pakistan \\ *Corresponding author's email: ecobiologian@yahoo.com
}

Citation

Asmat Ullah, Shahid Iqbal, Muhammad Qasim and Furhan Iqbal. Oral supplementation of ethanolic extract of Bauhinia variegata leaves did not disturbed the hematological and serum biochemical profile of adult albino mice. Pure and Applied Biology. Vol. 6, Issue 3, pp857-863. http://dx.doi.org/10.19045/bspab.2017.60090

\begin{tabular}{llll}
\hline \hline Received: $15 / 05 / 2017$ & Revised: $11 / 07 / 2017$ & Accepted: $17 / 07 / 2017$ & Online First: 20/07/2017 \\
\hline
\end{tabular}

\section{Abstract}

Flower buds, flowers, leaves, stem, seed, roots and stem bark of Bauhinia variegate (B. variegate) are used for pharmacological purposes in various systems such as Homeopathy, Unani, and Ayurveda but little information is available regarding their drug transportation in living systems. Present study was designed to report the effect, if any, of $150 \mathrm{mg} / \mathrm{ml} \mathrm{solvent} / \mathrm{Kg}$ body weight of Bauhinia variegata leaf extract on hematology and selected parameters of serum biochemical profile of female and male albino mouse. Seven week old albino mice were weighed and fed orally either with $150 \mathrm{mg} / \mathrm{ml}$ solvent/ kg body weight of Bauhinia variegata leaf extract or saline solution for 17 days. Complete blood count and selected serological parameters were determined in both experimental treatments at the end of dose supplementation. Our results revealed that oral supplementation of $150 \mathrm{mg} / \mathrm{ml}$ solvent/ $\mathrm{kg}$ body weight of Bauhinia variegata leaf extract for 17 days did not affected $(\mathrm{P}>0.05)$ any of the studied parameters of complete blood count and serum biochemistry in both female and male albino mice. Hence, it is concluded that $150 \mathrm{mg} / \mathrm{ml}$ solvent/ $\mathrm{kg}$ body weight of Bauhinia variegata leaf extract can be safely administrated through oral route in albino mice.

Keywords: Bauhinia variegate; Ethanolic leaf extract; Serum biochemistry; Complete blood count; Albino mice

\section{Introduction}

Plants are the most precious resource for an extensive range of derivative metabolites utilized as medicine, agrochemicals, biopesticides, food additives and flavors [1]. Bauhinia variegata L (Synonyms: Phanera variegata Benth) commonly known as mountain ebony, orchid-tree, poor-man's orchid, camel's foot and Napoleon's hat belongs to the family Leguminosae is a very popular small deciduous ornamental tree grown for its scented flowers [2-4]. All parts of this plant (leaves, flower buds, flower, stem, stem bark, seeds and roots) are reported to be used in traditional medicine [5]. It is traditionally used in the treatment of 
bronchitis, leprosy, and tumors. Infusion of the leaves is used as a laxative and for the treatment of piles $[6,7]$.

The phytochemical screening has revealed that Bauhinia variegata contains terpenoids, flavonoids, tannins, saponins, reducing sugars, steroids and cardiac glycosides [811]. A number of pharmacological studies has documented that Bauhinia variegata has anticancer, antioxidant,anti-hyperlipidemic, antidiabetic, antimicrobial,antiinflammatory, nephro-protective, hepatoprotective, antiulcer, immunomodulating, molluscicidal and wound healing effects [7, 12-17]. Despite of its biological importance, limited information is available in literature regarding its potential effects on complete blood count and serum biochemistry. The aim of this study was to determine the effect of $150 \mathrm{mg} / \mathrm{ml}$ solvent/ $\mathrm{kg}$ body weight of Bauhinia variegata leaf extract on complete blood count and on selected serological parameters in female and male albino mice.

\section{Materials and methods Subjects}

In order to demonstrate the effect of Bauhinia variegata leaf extract on hematology and selected parameters of serum biochemistry seven week old albino mice of both genders $(\mathrm{N}=28$, male $=14$ and female $=14$ ) were used as experimental animals in this study. Breeding pairs of albino mice were donated by Department of Zoology, Quaid-e-Azam campus, Punjab University Lahore, Pakistan, reared and maintained at the animal facility of Bahauddin Zakariya University Multan in Bio- Park. Animals were kept in locally manufactured small rodent cages filled with wood chips. In breeding colony, standard mouse diet and water were available $a d$ libitum. Room temperature was maintained at $22 \pm 1^{\circ} \mathrm{C}$. The light/dark rhythm was maintained at 14:10. The room was illuminated with artificial light at an intensity of about 200 Watt from 8 a.m. to 6 p.m. All experimental protocols and animal handling procedures were approved by ethical review board of Institute of Pure and Applied Biology, Bahauddin Zakariya University Multan, Pakistan.

Preparation of Bauhinia variegata leaf extract

The leaves of Bauhinia variegata were collected from different places in Multan, Pakistan. The leaves were thoroughly washed with distilled water and air dried under shade for about 15-20 days. The completely dried leaf samples were grounded to fine powder in a grinder (Waring, USA) and stored in air tight polythene bags at room temperature before further processing. The dried powder (200 grams) was soaked in $70 \%$ ethanol solvent for about 9 days in a brown colored amber bottle to avoid sunlight. The bottle with soaked material was shook 3-4 times a day and lid of bottle was opened for a few seconds to evaporate fumes produced and lid was tightly closed after that. Every third day, the material was filtered through a filtration assembly by using a Whatman filter paper to avoid impurities and residue were re-soaked in $70 \%$ ethanol solvent. On the $9^{\text {th }}$ day the filtrate was passed through Rota vapor (Buchi Rota-vapor R-205, Switzerland) by keeping the temperature of chiller at $37{ }^{\circ} \mathrm{C}$ until extract was separated from ethanol. The extract was further dried in an electric oven at $40{ }^{\circ} \mathrm{C}$ until maximum ethanol was evaporated and then it took the form a dark green gummy residue. From this paste, $150 \mathrm{mg}$ was taken and dissolved in 1 $\mathrm{ml}$ of distilled water to prepare the stock solution of Bauhinia variegata leaf extract following [18].

\section{Experimental design}

Following weaning, male and female mice were separated from their parents and were kept individually in cages until they were seven week old. At this point, animals were 
divided into two groups. First group was orally supplemented with $150 \mathrm{mg} / \mathrm{ml}$ solvent/ kg body weight of Bauhinia variegata leaf extract $(\mathrm{N}=14)$, While the second group was orally supplemented with saline solution for 17 days.

\section{Blood and serum collection}

At the end of experimental treatment, blood was sampled either through cardiac puncture or from retro-orbital sinus under Isoflurane (3\%) inhalation. For the analysis of serum biochemical parameters and for the determination of complete blood count in male and female albino mice, blood was divided into two parts respectively.

Hematological and serum biochemical profiling

Complete blood count (mean corpuscular volume, mean corpuscular hemoglobin concentration, packed cell volume, hemoglobin level, total red and white blood cell count, total lymphocytes count, total platelets count, red blood cell distribution width, platelets distribution width and large platelet concentration ratio) was determined in treated and untreated albino mice by using hematology analyzer FMI- 6180 (Jiangsu, China) following [19]. While serum biochemical parameters [Cholesterol, Alanine transaminase (ALT), Aspartate transaminase (AST), Total protein, creatinine and triglycerides] were analyzed in serum samples by using Hitachi 902 automatic analyzer (Japan) following the instructions of diagnostic kit manufacturers following Qadir [20].

Statistical analysis

All the data is expressed as Mean \pm Standard error of mean. Statistical package Minitab (version 17, Pennsylvania) was used for the statistical analysis of the results. Two sample t-test was used to compare all studied parameters of complete blood count and serum biochemistry between Bauhinia variegata and saline treated female and male albino mice.

\section{Results}

Effect of Bauhinia variegata on complete blood count of female and male albino mice

Analysis of the results revealed that all the studied parameters of complete blood counting varied non significantly $(\mathrm{P}>0.05)$ when compared between Bauhinia variegata leaf extract treated and untreated female and male albino mice (Table 1).

Table 1. Comparison of various studied hematological parameters between adult albino mice (of both genders) treated with Bauhinia variegata $(150 \mathrm{mg} / \mathrm{ml}$ solvent / $\mathrm{kg}$ body weight) or saline solution for 17 days. (Treated $N=7$ for each treatment). All values are expressed as mean \pm slandered deviation. P-value presents the results of 2 sample t-test conducted for each parameter between the two treated groups

\begin{tabular}{|c|c|c|c|c|c|c|}
\hline \multirow[t]{2}{*}{ Parameters } & \multicolumn{3}{|c|}{ Female mice } & \multicolumn{3}{|c|}{ Male mice } \\
\hline & $\begin{array}{l}\text { Saline } \\
\text { treatment }\end{array}$ & $\begin{array}{l}\text { Bauhinia } \\
\text { variegata } \\
\text { treatment }\end{array}$ & $P$ - value & $\begin{array}{l}\text { Saline } \\
\text { treatment }\end{array}$ & $\begin{array}{l}\text { Bauhinia } \\
\text { variegata } \\
\text { treatment }\end{array}$ & $P$ - value \\
\hline $\operatorname{RBC}\left(\times 10^{6} \mu L^{-1}\right)$ & $4.49 \pm 1.68$ & $4.74 \pm 154$ & 0.78 & $5.44 \pm 0.8$ & $4.94 \pm 1.33$ & 0.5 \\
\hline WBC $\left(\times 10^{3} \mu L^{-1}\right)$ & $7.87 \pm 2.6$ & $9.99 \pm 4.61$ & 0.32 & $10.31 \pm 4.52$ & $9.89 \pm 3.7$ & 0.84 \\
\hline HGB $\left(\mathrm{gdL}^{-1}\right)$ & $9.07 \pm 5.73$ & $12.51 \pm 4.29$ & 0.23 & $12.74 \pm 2.57$ & $10.71 \pm 3.43$ & 0.24 \\
\hline HCT (\%) & $36.9 \pm 13.7$ & $39.5 \pm 12.3$ & 0.72 & $42.79 \pm 6.67$ & $36.84 \pm 7.04$ & 0.13 \\
\hline MCV (fl) & $84.67 \pm 8.69$ & $83.60 \pm 2.38$ & 0.76 & $79.5 \pm 11.0$ & $76.9 \pm 14.3$ & 0.71 \\
\hline MCH (pg) & $22.6 \pm 11.2$ & $26.31 \pm 2.16$ & 0.43 & $23.59 \pm 3.84$ & $22.63 \pm 7.65$ & 0.77 \\
\hline $\operatorname{MCHC}\left(\mathrm{gdL}^{-1}\right)$ & $26.6 \pm 12.3$ & $31.47 \pm 2.37$ & 0.34 & $29.54 \pm 1.62$ & $28.89 \pm 6.46$ & 0.8 \\
\hline PLT $\left(\times 10^{3} \mu \mathrm{L}^{-1}\right)$ & $200.0 \pm 67.0$ & $260 \pm 12$ & 0.28 & $175.4 \pm 88.2$ & $235 \pm 144$ & 0.37 \\
\hline LYM (\%) & $39.5 \pm 12.6$ & $31.1 \pm 12.8$ & 0.24 & $31.6 \pm 12.7$ & $32.8 \pm 16.3$ & 0.88 \\
\hline
\end{tabular}




\begin{tabular}{|l|l|l|l|l|l|c|}
\hline MXD (\%) & $9.87 \pm 3.69$ & $10.06 \pm 3.43$ & 0.92 & $10.10 \pm 3.04$ & $8.06 \pm 2.86$ & 0.22 \\
\hline NEUT(\%) & $56.4 \pm 14.3$ & $58.9 \pm 14.4$ & 0.75 & $58.3 \pm 13.6$ & $59.5 \pm 18.0$ & 0.89 \\
\hline LYM (\%) & $2.48 \pm 0.768$ & $3.04 \pm 2.47$ & 0.59 & $2.77 \pm 0.79$ & $2.97 \pm 1.93$ & 0.81 \\
\hline MXD (\%) & $0.84 \pm 0.445$ & $1.09 \pm 0.886$ & 0.64 & $1.04 \pm 0.588$ & $0.74 \pm 0.199$ & 0.24 \\
\hline NEUT (\#) & $4.06 \pm 1.80$ & $5.86 \pm 3.15$ & 0.23 & $6.50 \pm 3.74$ & $16.17 \pm 4.21$ & 0.88 \\
\hline RDW (\%) & $34.6 \pm 15.9$ & $45.50 \pm 3.94$ & 0.16 & $42.69 \pm 3.53$ & $37.6 \pm 15.6$ & 0.43 \\
\hline PDW (\%) & $10.05 \pm 0.38$ & $11.37 \pm 1.6$ & 0.08 & $9.06 \pm 4.72$ & $5.84 \pm 4.04$ & 0.2 \\
\hline MPV (fl) & $7.85 \pm 0.229$ & $8.229 \pm 0.53$ & 0.13 & $6.73 \pm 3.15$ & $5.04 \pm 3.45$ & 0.36 \\
\hline
\end{tabular}

RBC: red blood cell, WBC: white blood cell, HGB: hemoglobin concentration, HCT: hematocrit, MCV: mean corpuscular volume, MCH: mean corpuscular hemoglobin, MCHC: mean corpuscular hemoglobin concentration, PLT: Platelet, LYM: Lymphocyte, MXD: Relative (\%) content of the mixture of monocytes , basophils , and eosinophils, NEUT: Neutrophils, LYM: Lymphocytes, RDW: Red cell distribution width, PWD: Platelet distribution width, MPV: Mean platelet volume. P> $0.05=$ Non significant.

Effect of Bauhinia variegata on serum biochemistry of female and male albino mice

Analysis of the results revealed that all the studied parameters of serum biochemical profile varied non-significantly $(\mathrm{P}>0.05)$ when compared between Bauhinia variegata leaf extract treated and untreated female and male albino mice (Table 2).

Table 2. Comparison of various studied serum biochemical parameters between adult albino mice (of both genders) treated with Bauhinia variegata $(150 \mathrm{mg} / \mathrm{ml}$ solvent $/ \mathrm{kg}$ body weight) or saline solution for 17 days treated $(\mathrm{N}=7$ for each treatment). All values are expressed as mean \pm slandered deviation. P-value presents the results of 2 sample t-test conducted for each parameter between the two treated groups

\begin{tabular}{|l|l|l|c|l|l|c|}
\hline \multicolumn{1}{|c|}{ Parameters } & \multicolumn{3}{|c|}{ Female mice } & \multicolumn{3}{c|}{ Male mice } \\
\cline { 2 - 7 } & $\begin{array}{l}\text { Saline } \\
\text { treatment }\end{array}$ & $\begin{array}{l}\text { Bauhinia } \\
\text { variegata } \\
\text { treatment }\end{array}$ & P - value & $\begin{array}{l}\text { Saline } \\
\text { treatment }\end{array}$ & $\begin{array}{l}\text { Bauhinia } \\
\text { variegata } \\
\text { treatment }\end{array}$ & P - value \\
\hline ALT (IU/L) & $140.1 \pm 59.2$ & $191.4 \pm 15.2$ & 0.07 & $139.8 \pm 29.1$ & $163.9 \pm 41.8$ & 0.24 \\
\hline AST (IU/L) & $158 \pm 135$ & $185.1 \pm 8.32$ & 0.61 & $120.0 \pm 35.3$ & $119.0 \pm 68.2$ & 0.09 \\
\hline Total proteins (g/dl) & $8.21 \pm 2.39$ & $9.66 \pm 1.11$ & 0.19 & $9.43 \pm 2.16$ & $8.67 \pm 2.21$ & 0.53 \\
\hline $\begin{array}{l}\text { Triglycerides } \\
\text { (mg/dl) }\end{array}$ & $246 \pm 139$ & $333.3 \pm 39.8$ & 0.16 & $278 \pm 109$ & $293.9 \pm 69.5$ & 0.76 \\
\hline Creatinine (mg/dl) & $0.357 \pm 0.15$ & $0.457 \pm 0.18$ & 0.29 & $0.429 \pm 0.19$ & $0.471 \pm 0.32$ & 0.76 \\
\hline Cholesterol (mg/dl) & $67.1 \pm 29.2$ & $48.9 \pm 18.0$ & 0.19 & $78.0 \pm 29.8$ & $76.3 \pm 59.6$ & 0.95 \\
\hline
\end{tabular}

Where ALT: Alanine transaminase, AST: Aspartate aminotransferase. $\mathrm{P}>0.05=$ Non significant (NS)

\section{Discussion}

Medicinal plants, as potential source of therapeutic aids, have attained significance in health system, for both humans and animals, all over the world not only in diseased condition but also for maintaining proper health [21]. The genus Bauhinia belongs to the family Caesalpiniaceae (formally Leguminosae) and several members of this genus like Bauhinia manca,
Bauhinia divaricata, Bauhinia purpurea and Bauhinia variegata are known for their medicinal importance [5, 22-25]. This study was conducted to determine the effect of $150 \mathrm{mg} / \mathrm{ml}$ solvent/ $\mathrm{kg}$ body weight of Bauhinia variegata leaf extract on hematology and serum biochemical parameters of adult female and male albino mice. Our results revealed that all the studied hematological parameters varied non 
significantly $(\mathrm{P}>0.05)$ when compared between the $B$. variegata leaf extract treated and untreated albino mice of both genders, indicating that $B$. variegata has no effect on hematology and can be supplemented orally as well as intravenously as therapeutic agent with no side effects (Table 1). Our results are in agreement with Jacobo et al. [26] as they did not observed any significant change in red blood cell, white blood cell, platelet count and in hemoglobin concentrations when compared between rodents, of both genders, exposed to variable doses of Bauhinia purpurea leaf extract.

It was observed that all the studied serological parameters also varied nonsignificant $(\mathrm{P}>0.05)$ when compared between Bauhinia variegata leaf extract treated female and male mice and their respective untreated control group (Table 2). Our results are in agreement with Jacobo et $a l$. as they reported that all of the parameters in serum biochemistry analysis were within normal range in the $B$. purpurea treated adult female and male albino rats [26]. Pani et al. [27] has reported that the serum creatinine decreased significantly in $B$. variegata stem extract treated mice as compared with the control group [27]. Balamurugan and Muralidharan [28] has also reported that the oral administration of methanolic extract of $B$. variegata (200 $\mathrm{mg} / \mathrm{kg}$ ) induced obese animals resulted in decreased total cholesterol and triglycerides levels in serum [28]. Abduljassim et al. [29] reported that the treatment with B.variegata ethanolic leaf extract significantly reduced the total cholesterol and triglyceride in Plasma in diabetic mice [29].

\section{Conclusions}

In conclusion, we are reporting that $150 \mathrm{mg} /$ $\mathrm{ml}$ solvent/ $\mathrm{kg}$ body weight of $B$. variegata leaf extract orally supplemented for 17 days to female and male albino mice did not affect the complete blood count and studied parameters of serum biochemistry and can be safely administrated orally as therapeutic agent.

\section{Authors' contributions}

Designed the study: F Iqbal, Lab experiments: A Ullah, S Iqbal \& M Qasim, Analyzed the data: Asmatullah, S Iqbal \& M Qasim, Wrote the manuscript: F Iqbal.

\section{References}

1. Iqbal F, Jahangir M, Ullah A, Khattak MNK \& Iqbal S (2017). Oral supplementations of Bauhinia variegata's leaf extract has anxiolytic effect and mproves locomotory and exploratory behavior of female albino mice. Int $J$ Phytomed 9(2): DOI:http://dx.doi.org/10.5138/09750185. 2073.

2. Sharma RK (2010). Pharmacological evaluation of Bauhinia variegate Linn. for wound healing and nephroprotective activity. PhD thesis, Rajiv Gandhi University of Health Sciences, Karnataka.

3. Hocking D (1993). Trees for dry lands. Oxford \& IBH Publishing Co. New Delhi.

4. Kanak S \& Verma AK (2012). Evaluation of antimicrobial and anticancer activities of methanol extract of in vivo and in vitro grown Bauhinia variegata $\mathrm{L}$. Int Res J Biol Sci (6): 26-30.

5. Khan V, Najmi AK, Akhtar M, Aqil M, Mujeeb M \& Pillai KK (2012). A pharmacological appraisal of medicinal plants with antidiabetic potential. Journal of Pharmacy and Bioallied sciences 4(1): 27.

6. Kumar D, Parcha V, Maithani A \& Dhulia I (2011). Effect and evaluation of anti hyperlipidemic activity of fractions of total methanol extract of Bauhinia variegata (Linn.) leaves on Triton WR1339 (Tyloxapol) induced hyperlipidemic rats. Int J Res Pharma Sci 2(4): 493497. 
7. Sonum P \& Agrawal RC (2009). Effects of Bauhinia variegate bark extract on DMBA induced mouse skin carcinogenesis: A preliminary study. Global J Pharmacol 3(3): 158-162.

8. Arain S, Memon N, Raiput MT, Sherazi S, Bhanger M \& Mahesar SA (2012). Physico -chemical characteristics of oil and seed residues of Bauhinia variegata and Bauhinia linnaei. Pak. J Anal Environ Chem 13(1): 16-21.

9. Dhale AD (2011). Phytochemical screening and antimicrobial activity of Bauhinia variegata Linn. $J$

Ecobiotechnol 3(9): 47.

10. EVANS WC (1989). Pharmacognosy 13th (Eds) Balliere Tindal, London. 419420.

11. Frankish N, De Souza F, Mills C \& Sheridan H (2004). Enhancement of Insulin Release from the B-Cell Line INS-1 by an Ethanolic extract of Buahinia variegate and Its major constituent. Planta Med 70: 421-426.

12. Rajkapoor B,Jayakar B, Murugesh N \& Sakthisekaran D (2006). Chemoprevention and cytotoxic effect of Bauhinia variegate against $\mathrm{N}$ nitrosodiethylamine induced liver tumors and human cancer cell lines. $J$ Ethnopharmacol 104: 407- 409.

13. Ali AS (2004). The Wealth of India, A Dictionary of Indian Raw Material and industrial products, raw material. Publication and Information Directorate, CSIR, New Delhi 3: 526555.

14. Gautam B, Vadivel V, Stuetz W \& Biesalski HK (2011). Bioactive compounds extracted from Indian wild legume seeds: antioxidant and type II diabetes related enzyme inhibition properties, Int J Food Sci Nutrit 1-4.

15. Ghaisas MM, Shaikh SA \& Deshpande AD (2009). Evaluation of the immunomodulatory activity of ethanolic extract of the stem bark of Bauhinia variegata Linn. Int J Green Pharma 3.1: 70.

16. Prusty KB, Harish B \& Mamatha CH (2012). Evaluation of Nephroprotective Activity of the Methanolic Extract of Leaves of Bauhinia variegata L. Fabaceae (Leguminosae)/Pea Family. $J$ Pharma Sci Tech 2(1): 16-19.

17. Rajani GP \& Ashok P (2009). In vitro antioxidant and antihyperlipidemic activities of Bauhinia variegata Linn. Indian J Pharmacol 41: 227-232.

18. Zahra NA (2015). Study the effect of Bauhinia variegate Linn. ethanolic extract on reducing glucose and lipid levels of white albino mice. Int $J$ Curr Microbiol App Sci 4(3): 652-658.

19. Khadim N, Iqbal S, Gillani Q, Safdar S, \& Iqbal F (2013). Supplementation of GABA-B Recepter Antagonist (CGB 55845), Following Hypoxia Ischemia Encephalography Moderately Affects the Hmatological and Serum Biochemical Profile in Albino mice. Pak J Zool 45(4): 1164-1167.

20. Qadir S (2015). Effect of imidacloprid exposure on the histology of selected vital organs, hematology and serum biochemical profile of Labeo rohita. Ph D thesis. Bahauddin Zakariya University Multan, Pakistan.

21. Verma S \& Singh SP (2008) .Current and future status of herbal medicines. Vet World 1(11): 347-350.

22. Ivorra MD, Paya M \& Villar A (1989). A review of natural products and plants as potential antidiabetic drugs. Ethnopharmacol 27: 243-245.

23. Viana EP, Santa-Rosa RS, Almeida SS \& Santos LS (1999). Constituents of the stem bark of Bauhinia guianensis .Fitoterapia 70: 111-112.

24. Panda S \& KAR S (1999). Withaniasomnifera and Bauhinia purpurea in the regulation of circulating 
thyroid hormone concentrations in female mice. J Ethnopharmacol 67: 233239.

25. Vasconcelos F, Sampaio S \& Arantes EC (2000) Efeitos de extrato de Bauhinia forficata. In: XI Reunia o Anual das federac,ões de Sociedades de Biologia Experimental. Caxambu, $M G$, Brazil 216.

26. Jacobo EG, Jiang Z, Yang J \& Li Z (2014). Composition and methods for Affecting mental state and body composition.US 20140134283A1.

27. Saumya R, Pani, Satyaranjan M, Sabuj S \& Prasana KP (2011). Nephroprotective effect of Bauhinia variegata (Linn.) whole stem extract against cisplatininduced nephropathy in rats. Indian $J$ Pharmacol 43(2): 200-202.

28. Balamurugan $G$ \& Muralidharan $P$ (2010). Antiobesity effect of Bauhinia variegata bark extract on female rats fed on hyper caloric diet. Bangladesh $J$ Pharmacol 5: 8-12.

29. Abduljassim M, Aljobouril, Khaleel I, Rashid, Sura A, Ibrahim, Abdul AJ \& Zahra NA (2015). Study the effect of Bauhinia variegate Linn. ethanolic extract on reducing glucose and lipid levels of white albino mice. Int J Curr Microbiol App Sci 4(3): 652658. 